\title{
PENGARUH AKUNTANSI NILAI WAJAR TERHADAP MANAJEMEN LABA: PERAN MODERASI STATUS PERUSAHAAN DALAM INDEKS SAHAM SYARIAH INDONESIA
}

\author{
Maisya Pratiwia, ${ }^{*}$, Dodik Siswantorob \\ a,bUniversitas Indonesia, Jl. Prof. Dr. Sumitro Djojohadikusumo Kukusan \\ Beji, Depok, Indonesia \\ *(maisyapratiwi@gmail.com)
}

\begin{abstract}
ABSTRAK
Tujuan dari penelitian ini adalah untuk mengetahui pengaruh nilai wajar (fair value) terhadap manajemen laba. Selain itu, penelitian juga bertujuan untuk mengetahui status perusahaan dalam Indeks Saham Syariah Indonesia (ISSI) dalam memoderasi pengaruh nilai wajar terhadap manajemen laba. Peneliti menguji perusahaan sektor non keuangan yang terdaftar di Bursa Efek Indonesia sebanyak 192 perusahaan selama tahun 2012-2016. Metode analisis data yang digunakan adalah model regresi random effect. Hasil penelitian menunjukkan bahwa nilai wajar tidak berpengaruh signifikan terhadap manajemen laba. Namun ketika nilai wajar dibagi berdasarkan hierarkinya, hasil penelitian menyatakan bahwa hanya nilai wajar 2 dan 3 memiliki pengaruh signifikan terhadap manajemen laba. Selain itu, hasil penelitian menyatakan bahwa perusahaan yang terdaftar dalam Indeks Saham Syariah Indonesia dapat mengurangi pengaruh nilai wajar terhadap manajemen laba, terutama pengaruh nilai wajar hierarki 2 dan 3 terhadap manajemen laba dibandingkan dengan nilai wajar hierarki 1.
\end{abstract}

Kata kunci: Nilai Wajar; Manajemen Laba; Saham Syariah

\begin{abstract}
This study aimed to examine the effect of fair value accounting on earnings management. The study also aimed to determine the companies' status in Indonesia Sharia Stock Index (ISSI) in moderating the effect of fair value on earnings management. We analysis 192 the non-financial sector companies listed on the Indonesia Stock Exchange from the years of 2012-2016. The result shows that fair value has no significant effect on earnings management. But, when fair value is divided based on fair value hierarchies, the result shows that only hierarchy 2 and 3 fair value has significant effect on earning management. In addition, the other result shows that the companies listed in the Indonesia Sharia Stock Index (ISSI) reduce the positive effect of fair value on earnings management, especially the effect of hierarchy 2 and 3 fair value on earnings management. Keywords: Fair Value; Earning Management; Sharia Stock
\end{abstract}




\section{PENDAHULUAN}

Akuntansi

nilai

wajar

memungkinkan manajemen untuk melakukan manajemen laba. Hal tersebut terjadi karena pengukuran nilai wajar dapat diukur selain dari nilai pasar (nilai wajar hierarki 1) yaitu dapat dilakukan dengan penilaian subjektif dari tim appraisal dan manajemen (nilai wajar hierarki 2 dan 3). Penentuan nilai wajar hierarki level 2 dan 3 menggunakan input yang dapat diobservasi dan tidak dapat diobservasi, hal tersebut tentunya bisa mengikutsertakan perkiraan subjektif yaitu judgement manajemen jika perusahaan tidak memiliki tim penilai yang independen. Salah satu judgement manajemen yaitu berupa penetapan discount rate dan default rate yang berdasarkan pada perkiraan subjektif manajemen.

Disebabkan pengukuran nilai wajar dapat menggunakan judgement manajemen, hal ini menjadi peluang bagi manajemen untuk melakukan manajemen laba. Hal tersebut didukung oleh Fargher dan Zhang (2014) menemukan bahwa nilai wajar memungkinkan earning management lebih tinggi, sehingga memberikan kualitas laba yang rendah di bank Amerika Serikat periode 2007-2011. Selain itu, Sodan (2015) yang meneliti perusahaan Eropa Timur selama tahun 2002-2011 menemukan bahwa peningkatan penggunaan nilai wajar dalam laporan keuangan akan mengakibatkan kualitas laba yang rendah disebabkan perusahaan di negara Eropa Timur lebih banyak mengestimasi nilai wajar menggunakan hierarki nilai wajar level 2 dan level 3. Akibatnya, manajemen laba yang tinggi dapat membuat pengguna laporan keuangan melakukan kesalahan dalam pengambilan keputusan.

Penelitian menjadikan status perusahaan yang terdaftar dalam Indeks Saham Syariah Indonesia (ISSI) sebagai moderasi mengingat dalam perspektif syariah bahwa pengukuran nilai wajar lebih ditekankan untuk digunakan dibandingkan dengan historical cost. Pengukuran nilai wajar diharapkan menghasilkan informasi akuntansi yang lebih menggambarkan keadaan terkini, sehingga tidak menyesatkan bagi pengguna laporan keuangan. Hal tersebut didukung oleh Wahyuni (2017) menyatakan bahwa dalam perspektif syariah dibutuhkan pengukuran yang relevan untuk menggambarkan keadaan aset atau liabilitas saat ini berupa nilai wajar, sehingga dapat digunakan untuk pengambilan keputusan yang tepat oleh pengguna laporan keuangan.

Hameed et al. (2004) menyatakan bahwa pandangan 
Syariah membolehkan penggunaan prinsip nilai wajar di mana akuntansi nilai wajar tersebut hanya bisa digunakan bila terdapat dasar penilaian yang kuat dan bukan ditetapkan untuk memenuhi kebutuhan individu dari manajemen. Hal tersebut tentunya mendukung bahwa perusahaan yang terdaftar dalam ISSI akan kemungkinan besar menggunakan nilai wajar yang memiliki dasar penilaian yang kuat dan bukan untuk memenuhi kebutuhan pribadi manajemen, sehingga perusahaan yang terdaftar dalam ISSI dapat memoderasi pengaruh nilai wajar terhadap manajemen laba.

Selain itu, dalam perusahaan yang terdaftar dalam saham syariah diberlakukannya pengaturan membatasi besaran aset dan liabilitas agar memenuhi persentase tertentu. Pengaturan terkait aset dan liabilitas tersebut, tentunya berdampak terhadap pengukuran aset dan liabilitas melalui akuntansi nilai wajar, yang mana manajer sulit mendapatkan peluang untuk melakukan memanipulasi laporan keuangannya melalui pengukuran nilai wajar atas aset dan liabilitas pada perusahaan yang terdaftar di ISSI. Pengaturan yang ketat terkait penilaian aset dan kewajibanya yang membuat keleluasaan perusahaan yang terdaftar dalam ISSI dalam melakukan manajemen laba melalui nilai wajar berkurang, sehingga perusahaan yang terdaftar dalam ISSI tersebut dapat mengurangi pengaruh positif akuntansi nilai wajar terhadap manajemen laba.

Penelitian ini berkontribusi untuk mengetahui status perusahaan yang terdaftar dalam ISSI dalam mengurangi pengaruh akuntansi nilai wajar terhadap manajemen laba. Penelitian ini menarik untuk dilakukan karena didapatkan hasil yang beragam terkait penelitian sebelumnya mengenai pengaruh nilai wajar terhadap manajemen laba. Dalam penelitian mengenai nilai wajar terhadap manajemen laba ditemukan disatu sisi bahwa nilai wajar dapat digunakan sebagai alternatif untuk melakukan manajemen laba (Choi et al. 2015; Hu et al. 2015; Fargher dan Zhang, 2014). Dechow et al. (2010) menemukan manajer menggunakan fleksibilitas yang tersedia di aturan akuntansi nilai wajar gains from asset securitizations untuk perataan laba (income smoothing) karena dalam penilaian gains dari asset securitizations diperlukan asumsi seperti discount rate, default rate, dan prepayement rate sehingga memberikan keluluasaan bagi manajemen untuk melakukan manajemen laba. 
Disisi lain, ditemukan nilai wajar dapat mengurangi praktik manajemen laba (Badia et al. 2017; Iatridis dan Kilirgiotis, 2012). Iatridis dan Kilirgiotis (2012) menemukan revaluasi aset tetap yang tinggi menurunkan tingkat dari manajemen laba pada 239 perusahaan yang terdaftar di London Stock Exchange karena revaluasi dilakukan agar memperkuat laporan keuangan perusahaan. Penulis lebih menekankan pada hasil penelitian yang menyatakan bahwa nilai wajar dapat digunakan sebagai alternatif manajemen karena beberapa pengukuran nilai wajar dapat ditentukan oleh asumsi dan judgement manajemen, sehingga dapat digunakan oleh manajemen untuk melakukan manajemen laba.

Selain itu, penelitian ini menarik dilakukan karena setelah penulis melakukan telaah literatur yang ada, dari sepanjang pengetahuan penulis belum ada yang melakukan penelitian status perusahaan dalam ISSI untuk memoderasi pengaruh nilai wajar terhadap manajemen laba. Pengaruh nilai wajar yang diteliti bukan hanya total nilai wajar tetapi juga di analisis pengaruh hierarki nilai wajar yang terdiri dari nilai wajar hierarki 1, 2, dan 3 terhadap manajemen laba.

Penelitian ini disajikan dalam struktur berikut, bagian pertama adalah pendahuluan. Bagian kedua membahas tinjauan literatur dan perumusan hipotesis. Bagian ketiga menyajikan metode penelitian. Bagian keempat menyajikan hasil penelitian. Bagian kelima menyajikan pembahasan. Bagian terakhir membahas kesimpulan, implikasi, dan keterbatasan penelitian.

\section{TELAAH LITERATUR DAN PERUMUSAN HIPOTESIS}

\section{Akuntansi Nilai Wajar dan Manajemen Laba}

Disatu sisi, penelitian mendukung bahwa nilai wajar dapat mengurangi manajemen laba. Badia et al. (2017) menyatakan instrumen keuangan yang diukur melalui nilai wajar level 2 dan 3 dapat menurunkan insentif manajemen laba karena menekankan pada prinsip konservatisme. Selain itu, Iatridis dan Kilirgiotis (2012) menemukan revaluasi aset tetap yang tinggi menurunkan tingkat dari manajemen laba pada 239 perusahaan yang terdaftar di London Stock Exchange karena revaluasi dilakukan agar memperkuat laporan keuangan perusahaan. Menurut Griner (2015) menyatakan pemilihan pengukuran nilai wajar mengurangi insentif para manajer untuk mencapai tujuan manajemen laba. 
Disisi yang lain, di mana peneliti menemukan bahwa nilai wajar dapat meningkatkan manajemen laba. Dechow et al. (2010) menemukan manajer menggunakan fleksibilitas yang tersedia di aturan akuntansi nilai wajar gains from asset securitizations untuk perataan laba (income smoothing) karena dalam penilaian gains from asset securitizations diperlukan asumsi seperti discount rate, default rate, dan prepayement rate sehingga memberikan keluluasaan bagi manajemen untuk melakukan manajemen laba. Lalu Xu (2013) menemukan adanya hubungan positif antara pengukuran nilai wajar dan manajemen laba yang didorong oleh available-for-sale assets. Landsman (2007) menemukan nilai wajar mendorong manajer memiliki insentif untuk mengelola laba (income smoothing). Di mana dalam perumusan hipotesis pertama, penulis lebih menekankan pada hasil penelitian yang menyatakan bahwa nilai wajar dapat digunakan sebagai alternatif manajemen dalam melakukan manajemen laba karena beberapa pengukuran nilai wajar dapat ditentukan oleh judgement manajemen, sehingga dapat digunakan oleh manajemen untuk melakukan manajemen laba. Maka dari itu, hipotesis pertama dirumuskan sebagai berikut:

H1: Akuntansi nilai wajar berpengaruh signifikan positif terhadap manajemen laba.

\section{Akuntansi Nilai Wajar, Manajemen Laba, dan Status Perusahaan dalam ISSI}

Perusahaan yang terdaftar dalam ISSI bukan semua perusahaannya menyatakan bahwa merekapatuh terhadap syariah (sharia compliant), tetapi merupakan perusahaan yang minimum melanggar syariah dalam artian produk dan keuangannya (persentase utang per aset, piutang, dan kas), sehingga ada kemungkinan lebih besar bahwa perusahaan yang terdaftar dalam ISSI akan lebih jujur dalam menyajikan laporan keuangan. Pengukuran di dalam perseptif syariah lebih menekankan penggunaan nilai wajar dibandingkan historical cost. Hal tersebut tentunya mendukung bahwa perusahaan yang terdaftar dalam ISSI akan kemungkinan besar menggunakan nilai wajar yang memiliki dasar penilaian yang kuat dan bukan untuk memenuhi kebutuhan pribadi manajemen, sehingga perusahaan ISSI tersebut dapat mengurangi pengaruh positif akuntansi nilai wajar terhadap manajemen laba. Hameed et al. (2004) menyatakan bahwa 
pandangan Syariah menekankan penggunaan prinsip nilai wajar di mana akuntansi nilai wajar tersebut hanya bisa digunakan bila terdapat dasar penilaian yang kuat dan bukan ditetapkan untuk memenuhi kebutuhan individu dari manajemen.

Selain itu, apabila perusahaan terdaftar dalam indeks saham syariah, keuangan perusahaan tersebut diatur sesuai dengan persentase tertentu. Di mana keuangan perusahaan tersebut mengandung komponen liabilitas dan aset yang diukur dengan nilai wajar. Hal tersebut mengindikasikan adanya aturan membatasi besaran aset dan liabilitas memiliki dampak pada pengukuran aset dan liabilitas melalui akuntansi nilai wajar, sehingga manajer sulit mendapatkan peluang untuk melakukan manajemen laba melalui pengukuran nilai wajar atas aset dan liabilitas pada perusahaan yang terdaftar di ISSI. Hal tersebut tentunya membuat perusahaan yang terdaftar dalam ISSI lebih tidak mudah melakukan manajemen laba melalui nilai wajar. Maka dari itu, perusahaan yang terdaftar dalam ISSI dapat memoderasi hubungan nilai wajar terhadap manajemen laba.

Farooq dan Abdelbari (2015) menyatakan bahwa perusahaan yang terdaftar dalam saham syariah memiliki kharakteristik seperti rendahnya piutang, leverage, dan kas sehingga manajer memiliki peluang yang rendah untuk melakukan manajemen laba. Selain itu, perusahaan yang terdaftar dalam saham syariah diharapkan akan mengungkapkan informasi pada laporan keuangan merupakan informasi akuntansi yang lebih jujur sesuai dengan prinsip syariah dibandingkan dengan perusahaan yang tidak terdaftar dalam saham syariah. Maka dari itu, hipotesis kedua dirumuskan sebagai berikut:

H2: Perusahaan yang terdaftar dalam ISSI dapat memperlemah pengaruh positif akuntansi nilai wajar terhadap manajemen laba.

\section{Akuntansi Nilai Wajar Hierarki 1, 2, dan 3 dan Manajemen Laba}

$$
\text { Sodan (2015) meneliti }
$$
perusahaan Eropa Timur selama tahun 2002-2011 menemukan bahwa peningkatan penggunaan nilai wajar dalam laporan keuangan akan mengakibatkan kualitas laba yang rendah disebabkan perusahaan di negara Eropa Timur lebih banyak mengestimasi nilai wajar menggunakan hierarki nilai wajar level 2 dan level 3. Kualitas laba yang rendah terlihat dari manajemen laba yang tinggi. Selain itu, Hal tersebut didukung juga oleh Majid dan 
Haliding (2014) menyatakan bahwa pengukuran nilai wajar hierarki 2 dan 3 dinilai menggunakan perkiraan subjektif. Disebabkan pengukuran nilai wajar hierarki 2 dan 3 menggunakan perkiraan subjektif yaitu dapat menggunakan asumsi dan judgement manajemen dibandingkan dengan nilai wajar hierarki 1 menggunakan harga pasar, sehingga dapat mengakibatkan dengan tingginya penggunaan nilai wajar hierarki 2 dan 3 mengakibatkan lebih tingginya peluang manajemen dibandingkan dengan nilai wajar hierarki 1. Maka dari itu, hipotesis ketiga dirumuskan sebagai berikut:

H3: Akuntansi nilai wajar hierarki 2 dan 3 memiliki pengaruh positif signifikan yang lebih kuat terhadap manajemen laba dibandingkan akuntansi nilai wajar hierarki 1.

\section{Akuntansi Nilai Wajar Hierarki 1, 2, dan 3, Manajemen Laba, dan Status Perusahaan dalam ISSI}

Disebabkan pengukuran nilai wajar hierarki 2 dan 3 menggunakan perkiraan subjektif yaitu dapat menggunakan asumsi dan judgement manajemen dibandingkan dengan nilai wajar hierarki 1 menggunakan harga pasar. Hal tersebut dapat mengakibatkan dengan tingginya penggunaan nilai wajar hierarki 2 dan
3 maka manajemen memiliki peluang yang tinggi untuk menggunakan pengukuran nilai wajar hierarki 2 dan 3 sebagai alternatif manajemen melakukan manajemen laba yang lebih tinggi dibandingkan dengan nilai wajar hierarki 1. Disebabkan nilai wajar hierarki 2 dan 3 memiliki pengaruh positif yang lebih kuat terhadap manajemen laba, maka perusahaan yang terdaftar di ISSI lebih menekankan atas penilaian hierarki 2 dan 3 nilai wajar harus diukur melalui dasar penilaian yang kuat dan bukan untuk memenuhi kebutuhan pribadi manajemen dibandingkan nilai wajar hierarki 1 yang sudah memiliki harga pasar di kuotasi aktif. Maka dari itu, perusahaan yang terdaftar dalam ISSI dapat mencegah atau mengurangi lebih kuat atas penggunaan nilai wajar hierarki 2 dan 3 untuk melakukan manajemen laba dibandingkan penggunaan nilai wajar hierarki 1. Maka dari itu, hipotesis keempat dirumuskan sebagai berikut:

H4: Perusahaan yang terdaftar dalam ISSI dapat lebih memperlemah pengaruh positif nilai wajar hierarki 2 dan 3 terhadap manajemen laba dibandingkan nilai wajar hierarki 1. 


\section{METODE}

\section{Pemilihan Sample dan Data}

Populasi yang digunakan dalam penelitian ini adalah seluruh perusahaan go public yang terdaftar di Bursa Efek Indonesia periode 20122016 sebesar 2375 firm-years. Pemilihan sampel dilakukan berdasarkan kriteria sampel di mana perusahaan sektor keuangan dikeluarkan dalam sampel penelitian karena akun pada laporan keuangan dan perhitungan manajemen laba yang berbeda dibandingkan perusahaan sektor non keuangan. Dalam memenuhi kebutuhan penelitian, perusahaan telah menerbitkan laporan keuangan yang telah diaudit termasuk data terkait aset yang disajikan melalui nilai wajar minimal 1 periode.

Tabel 1. Prosedur Pemilihan Sampel Penelitian

\begin{tabular}{ll}
\hline Kriteria & Total \\
\hline 1. Total perusahaan berdasarkan Fact Book BEI tahun 2016 x 5 tahun & 2375 \\
2. Perusahaan yang tidak termasuk dalam sektor keuangan (Finance) & $(445)$ \\
3. Perusahaan yang terdaftar di BEI yang tidak secara berturut-turut & $(135)$ \\
menerbitkan laporan keuangan tahunan audit dari tahun 2012-2016 & \\
4. Perusahaan tidak memiliki aset yang disajikan melalui nilai wajar & $(325)$ \\
pada laporan posisi keuangan di salah satu periode penelitian & \\
\hline Total Observasi & $\mathbf{9 6 0}$
\end{tabular}

Sumber: tabel olahan sendiri (2017)

Operasional Variabel

Variabel dependen dalam penelitian ini adalah manajemen laba (EM). Dari beberapa penelitian sebelumnya ditemukan bahwa ada beberapa model yang digunakan untuk mengukur dan memprediksi manajemen laba. Penelitian ini menggunakan manajemen laba akrual karena bekaitan erat dengan manajemen laba melalui estimasi dan kebijakan manajemen yaitu pengukuran nilai wajar. Secara umum model tersebut mengukur manajemen laba dengan menghitung Discretionary Accrual (DA) yang didapat dari total akrual dikurangi non-discretionary accrual (NDA) menggunakan rumus regresi dimana total akrual adalah laba bersih dikurangi arus kas dari operasi. Dalam penelitian ini digunakan performance matched discretionary accruals (PMDA) yaitu model Modified-Jones dikembangkan lagi oleh Kothari et al. (2005) dalam menentukan manajemen laba karena model tersebut menghasilkan model statistik yang paling baik tercermin dari adjusted $\mathrm{r}^{2}$ yang tinggi dibandingkan dengan model manajemen laba lainnya. 
Variabel independen yang digunakan dalam penelitian berupa nilai wajar, nilai wajar hierarki 1 , dan nilai wajar hierarki 2 dan 3 . Nilai wajar yang digunakan merupakan nilai wajar yang terdapat pada aset di laporan keuangan dan tidak menggunakan nilai wajar yang terdapat di liabilitas. Menurut Ehalaiye (2017) dinyatakan bahwa nilai wajar aset lebih bisa mencakup semua pengukuran nilai wajar dibandingkan nilai wajar yang terdapat di liabilitas. Fiechter dan Farkas (2016) menyatakan nilai wajar liabilitas sulit di interpretasi perkiraan koefisien karena belum tentu investor menyetujui penyesuaian risiko kredit. Maka dari itu, penelitian ini lebih menggunakan nilai wajar aset. Nilai wajar tersebut mengikuti penelitian Siekkinen (2016) dinyatakan dalam bentuk nilai wajar aset dibagi dengan lembar saham.

Variabel moderasi yang digunakan dalam penelitian ini adalah perusahaan yang terdaftar dalam indeks saham syariah. Kode variabel dummy 1 jika perusahaan merupakan perusahaan yang terdaftar di Indeks Saham Syariah Indonesia dan selain itu 0 . Variabel kontrol dalam penelitian ini adalah ukuran perusahaan (SIZE), tingkat profitablitas (ROA/ return on assets), tingkat leverage (LEV), Kualitas auditor (AUD), dan kerugian (LOSS).

Ukuran perusahaan diproksikan dengan logaritma natural total aset. Lang dan Lundholm menyatakan bahwa perusahaan besar cenderung melakukan manajemen laba lebih tinggi karena sumber daya keuangan yang lebih memandai, sehingga keleluasaan dalam manajemen laba semakin tinggi. Dalam penelitian Gaio (2010) dinyatakan bahwa variabel control terhadap kualitas laba dapat berupa tingkat profitabilitas yaitu ROA. Dikatakan bahwa perusahaan yang memiliki ROA tinggi diharapkan akan menemukan hubungan yang positif terhadap manajemen laba. Penelitian Gaio (2010) menyatakan leverage bisa ditemukan pengaruh positif dan negatif terhadap kualitas laba. Leverage dtentukan dengan rumus total liabilitas dibagi dengan total aset. Disatu sisi, perusahaan yang memiliki leverage yang tinggi dituntut oleh kreditur menghasilkan informasi yang lebih transparan dilihat dari kualitas laba yang tinggi. Tetapi disisi lain, perusahaan yang memiliki leverage tinggi memiliki risiko dan biaya agensi yang tinggi, sehingga perusahaan berusaha untuk melakukan menutupi kinerja perusahaan yang sebenarnya yang 
tercermin dalam kualitas laba yang buruk.

Kualitas auditor (AUD) diproksikan dengan dummy jika 1 maka perusahaan itu diaudit oleh auditor BIG4 dan bernilai 0 jika sebaliknya. Jika perusahaan diaudit dengan auditor BIG4 maka diketahui bahwa memiliki kualitas audit yang baik maka kecenderungan perusahaan melakukan manajemen laba semakin kecil. Francis dan Wang (2008) menyatakan bahwa auditor BIG4 mencegah kliennya melakukan manajemen laba secara agresif demi menjaga reputasi auditor tersebut. Kerugian (LOSS) diproksikan dengan dummy jika 1 maka pada tahun itu perusahaan sedang mengalami kerugian dan bernilai 0 jika sebaliknya. Dalam penelitian Kim et al., (2012) dinyatakan bahwa manajemen laba dilakukan oleh perusahaan besar agar perusahaan tidak mengalami kerugian.

\section{Model Penelitian}

Model pengujian hipotesis 1 yaitu menguji pengaruh nilai wajar terhadap manajemen laba dijelaskan pada model 1 . Maka dari itu, berikut merupakan model 1:

$\mathrm{EMit}=\beta 0+\beta 1 \mathrm{FVA}+\beta 2 \mathrm{SIZE}+\beta 3 \mathrm{ROA}+$ $\beta 4 \mathrm{LEV}+\beta 5$ AUD $+\beta 6 \mathrm{LOSS}+\varepsilon i, \mathrm{t}$
Pengujian lebih lanjut untuk meneliti hipotesis 1 dan 2 dapat dijelaskan pada model 2 sebagai berikut:

$\begin{array}{lcc}\text { EMit }=\beta 0+ & \beta 1 \mathrm{FVA}+ & \beta 2 \mathrm{ISSI}+ \\ \beta 3 \mathrm{FVA}^{*}{ }^{*} \mathrm{SSI}+ & \beta 4 \mathrm{SIZE}+ & \beta 5 \mathrm{ROA}+\end{array}$ $\beta 6 \mathrm{LEV}+\beta 7 \mathrm{AUD}+\beta 8 \mathrm{LOSS}+\varepsilon \mathrm{i}, \mathrm{t}$

Model awal dari pengujian ini menggunakan Iatridis dan Kilirgiotis (2012) yang telah dimodifikasi. Di mana diketahui apabila penelitian sesuai prediksi hipotesis 1 maka nilai $\beta 1$ pada model 1 dan 2 akan bernilai positif signifikan yang berarti bahwa nilai wajar digunakan sebagai alternatif untuk melakukan manajemen laba. Apabila nilai $\beta 3$ pada model 2 akan bernilai negatif signifikan yang berarti bahwa perusahaan yang terdaftar dalam ISSI dapat menurunkan pengaruh nilai wajar terhadap manajemen laba, maka hipotesis 2 dapat diterima.

Model pengujian hipotesis 3 yaitu menguji pengaruh nilai wajar hierarki 1, 2, dan 3 terhadap manajemen laba dijelaskan pada model 3. Penulis memisahkan model total nilai wajar dan nilai wajar hierarki 1, 2, dan 3 agar tidak terjadi masalah multikolinearitas pada model. Maka dari itu, berikut merupakan model 3: 
EMit $=\beta 0+\quad \beta 1 \mathrm{FVA} 1+\quad \beta 2 \mathrm{FVA} 23+$ $\beta 3$ SIZE $+\beta 4 \mathrm{ROA}+\beta 5 \mathrm{LEVERAGE}+$ $\beta 6$ AUD $+\beta 7 \mathrm{LOSS}+\varepsilon \mathrm{i}, \mathrm{t}$

Pengujian hipotesis 3 dan 4 dapat dijelaskan pada model 4 sebagai berikut:

$\mathrm{EMit}=\beta 0+\beta 1 \mathrm{FVA} 1+\beta 2 \mathrm{FVA} 2+\beta 3 \mathrm{ISSI}+$ $\beta 4 \mathrm{FVA} 1 *$ ISSI $+\beta 5 \mathrm{FVA} 2 *$ ISSI $+\beta 6 \mathrm{SIZE}+$ $\beta 7 \mathrm{ROA}+\quad \beta 8 \mathrm{LEVERAGE}+\quad \beta 9 \mathrm{AUD}+$ $\beta 10 L O S S+\varepsilon i, t$

Di mana diketahui apabila penelitian sesuai prediksi hipotesis 3 maka nilai $\beta 2$ pada model 3 dan 4 akan bernilai positif signifikan lebih kuat dibandingkan dengan $\beta 1$. Hal tersebut berarti bahwa pengaruh nilai wajar hierarki 2 dan 3 lebih kuat terhadap manajemen laba dibandingkan nilai waar hierarki 1 . Apabila penelitian sesuai prediksi hipotesis 4 maka nilai $\beta 5$ pada model 4 akan bernilai negatif signifikan lebih kuat dibandingkan dengan $\beta 4$. Hal tersebut berarti bahwa perusahaan yang terdaftar dalam ISSI lebih memperlemah pengaruh nilai wajar hierarki 2 dan 3 terhadap manajemen laba dibandingkan nilai wajar hierarki 1.

Dimana:

EM : Manajemen Laba

FVA : Total aset yang diukur melalui nilai wajar per lembar saham
FVA1 : Total aset yang diukur melalui nilai wajar hierarki 1 per lembar saham

FVA23: Total aset yang diukur melalui nilai wajar hierarki 2 dan 3 per lembar saham

ISSI : Dummy variable, 1 jika perusahaan terdaftar dalam Indeks Saham Syariah Indonesia (ISSI) dan 0 sebaliknya.

FVA*ISSI : Variabel interaksi FVA dan ISSI

FVA1*ISSI : Variabel interaksi FVA1 dan ISSI

FVA23*ISSI : Variabel interaksi FVA23 dan ISSI

SIZE : Logaritma natural total aset

ROA : Rasio laba bersih terhadap total aset

LEV : Total liabilitas per aset

AUD : Dummy variable, 1 jika perusahaan diaudit oleh BIG4 dan 0 sebaliknya.

LOSS : Dummy variable, 1 jika perusahaan mengalami kerugian dan 0 sebaliknya.

\section{Teknik Analisis Data}

Penelitian ini menggunakan data panel, sehingga menganalisis data menggunakan software STATA 14. Sebelum dilakukan pengujian, langkah awal yaitu dilakukan analisis statistik deskriptif. Setelah itu, peneliti melakukan pemilihan metode estimasi data panel terdiri dari 
metode Pooled Least Square (PLS), metode Random Effect, dan metode Fixed Effect.

Setelah dilakukan pemilihan metode, maka dilakukan pengujian asumsi klasik. Pengujian asumsi klasik yang terdiri dari multikoliniearitas, heteroskedastisitas, dan autokorelasi berlaku untuk regresi data panel yaitu model Pooled Least Square dan Fixed Effects. Sedangkan metode random effect (RE) tidak membutuhkan pengujian heteroskedastisitas dan autokorelasi karena menggunakan pendekatan General Least Square (GLS), sehingga hanya menggunakan uji multikolinearitas saja.

HASIL DAN PEMBAHASAN
Penelitian ini menggunakan data balance panel yang diuji dengan model random effect. Semua asumsi klasik terkait model random effect yaitu multikolinearitas di mana didapatkan bahwa penelitian ini bebas dari multikolinearitas.

\section{Analisis Statistik Deskriptif}

Tabel 1 menggambarkan statistik deskriptif terkait data yang digunakan pada penelitian. Manajemen laba (EM) yang digunakan dalam penelitian berupa angka absolut karena dalam penelitian ini tidak melihat apakah manajemen labanya meningkatkan atau mengurangi, tetapi hanya melihat besaran dari manajemen laba yang dilakukan.

Tabel 2. Statistik Deskriptif Variabel

\begin{tabular}{llllll}
\hline Variabe1 & Mean & Median & SD & Min & Max \\
\hline EM & 0,080 & 0,053 & 0,102 & 0,0000 & 1,556 \\
FVA & 1.701 & 42,996 & 6.016 & 0 & 102.999 \\
& Miliar & Miliar & Miliar & & Miliar \\
FVA1 & 151,896 & 0,00 & 660,884 & 0,0000 & 6.822 \\
& Miliar & & Miliar & & Miliar \\
FVA23 & $1.438,707$ & 2,667 & $4.833,516$ & 0,00 & 52.350 \\
& Miliar & Miliar & Miliar & & Miliar \\
SIZE & 10.978 & 3.187 & 23.438 & 87,673 & 261.855 \\
& Miliar & Miliar & Miliar & Miliar & Miliar \\
ROA & 0,046 & 0,035 & 0,129 & $-1,072$ & 1,852 \\
LEV & 0,484 & 0,498 & 0,206 & 0,010 & 0,986 \\
\hline
\end{tabular}

Keterangan:

EM: manajemen laba; FVA: aset yang disajikan menggunakan nilai wajar; SIZE: total aset; ROA: Net Income dibagi aset; LEV: Liabilitas per aset

Sumber: tabel olahan sendiri (2017)

Secara rata-rata manajemen laba yang dilakukan oleh perusahaan sebesar 0.08. Nilai rata-rata perusahaan menyajikan asetnya 
berdasarkan nilai wajar (FVA) sebesar Rp1.701.087.358.563. Sebagian perusahaan tidak memiliki aset yang disajikan sebesar nilai wajar terlihat dari nilai terendah sebesar 0 (nol) di salah satu periode penelitian. Hasil penelitian menunjukan bahwa perusahaan menggunakan nilai wajar hierarki 2 dan 3 untuk menyajikan aset pada laporan posisi keuangan lebih banyak dibandingkan dengan aset yang disajikan dengan nilai wajar hierarki 1.

Rata-rata ukuran perusahaan sebesar Rp10.978.749.036.136. Ratarata kemampuan perusahaan dalam menghasilkan laba yang digambarkan oleh rasio profitabilitas berupa ROA (Return On Asset) sebesar 0,046. Rata-rata kemampuan perusahaan dalam melunasi hutangnya (Leverage/LEV) sebesar 0,484.
Tabel 3 menyatakan bahwa perusahaan yang terdaftar dalam Indeks Saham Syariah Indonesia (ISSI) lebih banyak dibandingkan dengan perusahaan yang tidak terdaftar dalam Indeks Saham Syariah Indonesia (ISSI). Hal tersebut mengindikasikan bahwa perkembangan saham syariah di Indonesia telah tinggi dilihat dari perusahaan yang terdaftar dalam Indeks Saham Syariah Indonesia (ISSI) sebesar 80.52\%. Selain itu, diketahui bahwa dari 960 perusahaan mengalami kerugian sebanyak $19.27 \%$ dan perusahaan yang tidak mengalami kerugian sebanyak 80.73\%. Laporan keuangan dari 960 perusahaan yang diaudit oleh auditor BIG4 sebanyak $46.46 \%$ sedangkan laporan keuangan yang diaudit oleh auditor non BIG4 sebanyak 53.54\%.

Tabel 3. Statistik Deskriptif Variabel Dummy

\begin{tabular}{cccc}
\hline Variabel & N & Dummy = 1 & Dummy = 0 \\
\hline ISSI & $\mathbf{9 6 0}$ & $80.52 \%$ & $19.48 \%$ \\
AUD & $\mathbf{9 6 0}$ & $46.46 \%$ & $53.54 \%$ \\
LOSS & $\mathbf{9 6 0}$ & $19.27 \%$ & $80.73 \%$ \\
\hline
\end{tabular}

\section{Keterangan:}

ISSI: dummy variable, 1 jika perusahaan terdaftar dalam Indeks Saham Syariah Indonesia (ISSI) dan ' 0 ' sebaliknya; AUD: dummy ' 1 ' jika perusahaan diaudit oleh auditor BIG4 dan 'O' sebaliknya; LOSS: dummy ' 1 ' jika perusahaan mengalami kerugian dan ' 0 ' sebaliknya.

Sumber: tabel olahan sendiri (2017)

Analisis Empiris

Tabel 4 menunjukan hasil pengujian model 1 dan model 2 . Nilai adjusted R-square pada model 1 cukup rendah menyatakan bahwa variabel independen dan variabel 
kontrol hanya mampu menjelaskan variabel dependen sebesar 2.59\%, sedangkan $97.41 \%$ dijelaskan oleh faktor lain yang tidak terdapat pada variabel penelitian. Dengan ditambahkan variabel moderasi, maka nilai adjsted R-square meningkat pada model 2 sebesar $5.31 \%$.

Tabel 4. Hasil Pengujian Model 1 dan Model 2

\begin{tabular}{|c|c|c|c|c|c|c|c|}
\hline \multirow[t]{2}{*}{ Variabel } & \multirow[t]{2}{*}{ Pred } & \multicolumn{3}{|c|}{ Model 1} & \multicolumn{3}{|c|}{ Model 2} \\
\hline & & Koef & Prob & & Koef & Prob & \\
\hline Constanta & & 0,0871722 & 0,000 & $* * *$ & 0,107878 & 0,0000 & $* * *$ \\
\hline FVA & + & $-0,00000001$ & 0,48 & & 0,000005 & 0,1495 & \\
\hline FVA*ISSI & - & & & & $-0,000008$ & 0,097 & * \\
\hline ISSI & - & & & & $-0,0195514$ & 0,004 & $* * *$ \\
\hline SIZE & + & $-0,0006133$ & 0,395 & & $-0,000446$ & 0,42 & \\
\hline ROA & + & $-0,0352861$ & 0,144 & & $-0,032578$ & 0,1595 & \\
\hline LEV & $+/-$ & $-0,015456$ & 0,167 & & $-0,0255167$ & 0,054 & * \\
\hline AUD & - & $-0,011098$ & 0,065 & $* *$ & $-0,010265$ & 0,0735 & * \\
\hline LOSS & + & 0,0178508 & 0,011 & $* *$ & 0,0154794 & 0,0235 & ** \\
\hline Adjusted $\mathbf{R}^{2}$ & & \multicolumn{2}{|c|}{0,0258} & & \multicolumn{3}{|c|}{0,0531} \\
\hline F-Statistic & & \multicolumn{2}{|c|}{0,0071} & & \multicolumn{3}{|c|}{0,0001} \\
\hline
\end{tabular}

Sumber: tabel olahan sendiri (2017)

Pada model 1 dan 2 didapatkan bahwa variabel FVA bernilai tidak signifikan yang menunjukkan nilai wajar tidak berpengaruh terhadap manajemen laba.Model 1 dan model 2 didapatkan hasil yang bertentangan mengenai tanda dari koefisien FVA. Pada model 1 didapatkan koefisien FVA bernilai negatif, sedangkan model 2 didapatkan koefisien FVA bernilai positif. Hal tersebut mengindikasikan bahwa semakin tinggi penggunaan ukuran nilai wajar terhadap aset maka manajemen laba perusahaan tersebut bisa saja turun ataupun meningkat.Namun hasil yang didapatkan yaitu tidak terdapat pengaruh signifikan akuntansi nilai wajar terhadap manajemen laba. Hal tersebut mengakibatkan hipotesis pertama ditolak bahwa akuntansi nilai wajar tidak berpengaruh signifikan terhadap nilai wajar. Hal tersebut mengindikasikan bahwa nilai wajar bukanlah alternatif utama bagi manajer untuk melakukan manajemen laba.

Pada model 2 dilakukan pengujian terkait pengaruh perusahaan yang terdaftar dalam ISSI memoderasi akuntansi nilai wajar terhadap manajemen laba.Variabel FVA*ISSI bernilai negatif dan signifikan pada tingkat 10\%.Hasil yang didapatkan bahwa perusahaan yang terdaftar dalam ISSI mengurangi 
pengaruh positif signifikan nilai wajar terhadap manajemen laba pada tingkat $10 \%$. Hal tersebut menyatakan bahwa hipotesis kedua diterima dengan tingkat signifikansi $10 \%$.

Tabel 5. Hasil Pengujian Model 3 dan Model 4

\begin{tabular}{|c|c|c|c|c|c|c|c|}
\hline \multirow[t]{2}{*}{ Variabel } & \multirow[t]{2}{*}{ Pred } & \multicolumn{3}{|c|}{ Model 3} & \multicolumn{3}{|c|}{ Model 4} \\
\hline & & Koef & Prob & & Koef & Prob & \\
\hline Constanta & & 0,0866132 & 0,0000 & $* * *$ & 0,1072980 & 0,0000 & $* * *$ \\
\hline FVA1 & + & $-0,0000109$ & 0,3050 & & 0,0000081 & 0,3945 & \\
\hline FVA23 & + & $-0,0000001$ & 0,2900 & & 0,0000081 & 0,1000 & * \\
\hline FVA1*ISSI & - & & & & 0,0000053 & 0,4510 & \\
\hline FVA23*ISSI & - & & & & $-0,000013$ & 0,0415 & $* *$ \\
\hline ISSI & - & & & & $-0,018904$ & 0,0060 & $* * *$ \\
\hline SIZE & + & $-0,0006947$ & 0,3835 & & $-0,000598$ & 0,3960 & \\
\hline ROA & + & $-0,0353988$ & 0,1425 & & 0,0341245 & 0,1480 & \\
\hline LEV & $+/-$ & $-0,0144368$ & 0,1860 & & $-0,025920$ & 0,0535 & * \\
\hline AUD & - & $-0,0103015$ & 0,0825 & * & $-0,009097$ & 0,100 & * \\
\hline LOSS & + & 0,0174547 & 0,0125 & $* *$ & 0,0153586 & 0,0245 & $* *$ \\
\hline Adjusted $\mathbf{R}^{2}$ & & \multicolumn{2}{|c|}{0,0277} & & \multicolumn{3}{|c|}{0,0550} \\
\hline F-Statistic & & \multicolumn{2}{|c|}{0,0109} & & \multicolumn{3}{|c|}{0,0000} \\
\hline
\end{tabular}

Sumber: tabel olahan sendiri (2017)

Tabel 5 menunjukan hasil pengujian model 3 dan model 4. Pada model 3 dan 4 dinyatakan bahwa total nilai wajar yang merupakan variabel independen dibagi berdasarkan hierarki yaitu nilai wajar tingkat 1 hierarki serta hierarki nilai wajar tingkat 2 dan 3 . Pembagian nilai wajar berdasarkan hierarkinya tidak digabungkan dalam model 1 dan 2 karena jika digabungkan maka terjadi multikolinearitas yang kuat yang mengakibatkan terjadinya kesalahan dalam pengambilan kesimpulan. Oleh sebab itu, nilai wajar yang terbagi atas hierarki pengukurannya dijelaskan dalam model penelitian 3 dan 4 .
Hasil pengujian model 3 menyatakan nilai adjusted R-square pada model 3 dan model 4 memiliki nilai yang cukup rendah sebesar 2,77\% dan 5,5\%. Variabel FVA23 bernilai positif dan signifikan dengan tingkat $10 \%$ pada model 4 . Hasil yang didapatkan bahwa hanya akuntansi nilai wajar hierarki 2 dan 3 yang memiliki pengaruh signifikan terhadap manajemen laba dengan tingkat $10 \%$. Hipotesis kedua dapat diterima bahwa akuntansi nilai wajar hierarki 2 dan 3 memiliki pengaruh positif signifikan yang lebih kuat terhadap manajemen laba dibandingkan akuntansi nilai wajar hierarki 1. 
Pada model 4 dilakukan pengujian terkait pengaruh perusahaan yang terdaftar dalam ISSI memoderasi akuntansi nilai wajar hierarki 1, 2, dan 3 akuntansi nilai wajar terhadap manajemen laba. Variabel FVA23*ISSI bernilai negatif dan signifikan pada tingkat 10\%, sedangkan variabel FVA1*ISSI bernilai positif dan tidak signifikan. Hasil yang didapatkan menyatakan bahwa status perusahaan yang terdaftar dalam ISSI lebih kuat dalam mengurangi pengaruh nilai wajar hierarki 2 dan 3 terhadap manajemen laba. Hal tersebut menyatakan bahwa hipotesis keempat diterima dengan tingkat signifikansi 5\%.

\section{Pembahasan}

Hasil keseluruhan dari pengujian hipotesis dapat dilihat pada tabel 6. Dari hasil tersebut didapatkan bahwa hipotesis 1 ditolak.Ditemukan bahwa akuntansi nilai wajar tidak berpengaruh signifikan terhadap nilai wajar.Hal tersebut mengindikasikan bahwa nilai wajar bukanlah alternatif utama bagi manajer untuk melakukan manajemen laba.

Hasil penelitian untuk menguji hipotesis 2 didapatkan bahwa perusahaan yang terdaftar dalam ISSI mengurangi pengaruh positif niai wajar terhadap manajemen laba.
Perusahaan yang terdaftar dalam ISSI merupakan perusahaan yang kemungkinan lebih besar akan lebih jujur dalam menyajikan laporan keuangan dibandingkan perusahaan yang tidak terdaftar dalam saham syariah. Obid dan Demikha (2011) menyatakan keputusan manajemen harus mematuhi prinsip syariah dengan melakukan aktivitas yang sah dan menghindari kegiatan yang telah dilarang oleh syariah. Hal tersebut membuat manajer harus melaporkan informasi akuntansi dalam laporan keuangan tercermin informasi yang jujur dan akurat. Maka dari itu, perusahaan yang terdaftar dalam ISSI menggunakan nilai wajar yang memiliki dasar penilaian yang kuat dan bukan untuk memenuhi kebutuhan pribadi manajemen sesuai dengan prinsip syariah, sehingga perusahaan ISSI tersebut dapat mengurangi pengaruh positif akuntansi nilai wajar terhadap manajemen laba.

Selain itu, manajer sulit mendapatkan peluang untuk melakukan manajemen laba melalui pengukuran nilai wajar atas aset dan liabilitas pada perusahaan yang terdaftar dalam syariah disebabkan oleh pengaturan terkait presentase keuangan di perusahaan ISSI yang tidak memberikan keleluasaan bagi manajemen untuk dilakukannya 
manajemen laba. Farooq dan Abdelbari (2015) menyatakan bahwa perusahaan yang terdaftar dalam saham syariah memiliki kharakteristik seperti rendahnya piutang, leverage, dan kas sehingga manajer memiliki peluang yang rendah untuk melakukan manajemen laba. Maka dari itu, hipotesis 2 diterima.

Hipotesis 3 dapat diterima bahwa akuntansi nilai wajar hierarki 2 dan 3 memiliki pengaruh positif signifikan yang lebih kuat terhadap manajemen laba dibandingkan akuntansi nilai wajar hierarki 1 . Hal tersebut terjadi karena pengukuran hierarki 2 dan 3 nilai wajar dapat menggunakan asumsi dan judgement manajemen, sehingga dapat mengakibatkan tingginya peluang manajemen untuk menggunakan pengukuran nilai wajar sebagai alternatif manajemen melakukan manajemen laba yang lebih tinggi dibandingkan nilai wajar hierarki 1 . Hasil penelitian ini didukung oleh Sodan (2015) yang meneliti perusahaan Eropa Timur selama tahun 2002-2011 menemukan bahwa peningkatan penggunaan nilai wajar dalam laporan keuangan akan mengakibatkan kualitas laba yang rendah disebabkan perusahaan di negara Eropa Timur lebih banyak mengestimasi nilai wajar menggunakan hierarki nilai wajar level 2 dan level 3. Kualitas laba yang rendah tergambarkan dalam manajemen laba yang tinggi.

Hipotesis 4 diterima bahwa status perusahaan yang terdaftar dalam ISSI lebih kuat dalam mengurangi pengaruh nilai wajar hierarki 2 dan 3 terhadap manajemen laba dibanding nilai wajar hierarki 1 . Pengukuran nilai wajar hierarki 2 dan 3 dapat menggunakan asumsi dan judgement manajemen dibandingkan dengan nilai wajar hierarki 1 menggunakan harga pasar. Hal tersebut dapat mengakibatkan bahwa nilai wajar hierarki 2 dan 3 lebih bisa diawasi pengukurannya oleh perusahaan. Selain itu, disebabkan nilai wajar hierarki 2 dan 3 memiliki pengaruh positif yang lebih kuat terhadap manajemen laba, maka perusahaan yang terdaftar di ISSI lebih menekankan atas penilaian nilai wajar hierarki 2 dan 3 harus diukur melalui dasar penilaian yang kuat dan bukan untuk memenuhi kebutuhan pribadi manajemen dibandingkan hierarki 1 nilai wajar yang sudah memiliki harga pasar di kuotasi aktif. Maka dari itu, perusahaan yang terdaftar dalam ISSI dapat mencegah atau mengurangi lebih kuat atas penggunaan nilai wajar hierarki 2 dan 3 untuk melakukan manajemen laba 
dibandingkan penggunaan nilai wajar hierarki 1.

Dari hasil penelitian juga didapatkan bahwa perusahaan yang terdaftar dalam ISSI melakukan manajemen laba yang rendah. Hal tersebut didukung oleh Ismail et al., (2015) menyatakan bahwa perusahaan yang terdaftar dalam saham syariah tunduk pada pengawasan yang ketat, sehingga mempunyai insentif tinggi dalam memberikan informasi akuntansi dengan kualitas yang tinggi. Kualitas informasi yang tinggi terlihat dari tingkat manajemen laba yang rendah.

Hasil penelitian terkait dengan variabel kontrol didapatkan bahwa semua variabel kontrol yang berbeda arah dari prediksi memiliki nilai yang tidak signifikan. Variabel kontrol yang tidak signifikan yaitu ukuran perusahaan (SIZE) dan ROA (Return on Asset). Lang dan Lundholm (1993) menyatakan bahwa perusahaan besar cenderung melakukan manajemen laba lebih tinggi karena sumber daya keuangan yang lebih memandai, sehingga keleluasaan dalam manajemen laba semakin tinggi. Dalam penelitian Gaio (2010) menyatakan perusahaan yang memiliki ROA tinggi akan menemukan hubungan yang positif terhadap manajemen laba, karena memiliki lebih banyak laba yang memberikan peluang lebih besar bagi manajemen dalam melakukan manajemen laba. Namun hasil penelitian tersebut tidak dapat dibuktikan pada penelitian ini, hal tersebut mengindikasikan bahwa perusahaan yang memiliki ukuran perusahaan dan tingkat profitabilitas yang besar bukan berarti melakukan manajemen laba yang tinggi

Variabel kontrol yang signifikan yaitu tingkat leverage (LEV), kualitas auditor (AUD), dan kerugian (LOSS). Perusahaan yang memiliki tingkat utang yang lebih tinggi dibanding asetnya akan melakukan manajemen laba yang rendah. Hal tersebut didukung oleh penelitian Gaio (2010) menyatakan leverage perusahaan yang memiliki leverage yang tinggi dituntut oleh kreditur menghasilkan informasi yang lebih transparan dilihat dari kualitas laba yang tinggi tercermin dari rendahnya manajemen laba. Selain itu, perusahaan yang laporan keuangannnya diaudit oleh auditor BIG4 maka akan melakukan manajemen laba yang lebih rendah. Francis dan Wang (2008) menyatakan bahwa auditor BIG4 mencegah kliennya melakukan manajemen laba secara agresif demi menjaga reputasi auditor tersebut. Perusahaan yang mengalami kerugian maka akan melakukan manajemen laba yang 
lebih tinggi. Dalam penelitian Kim et al., (2012) dinyatakan bahwa manajemen laba dilakukan oleh perusahaan besar agar perusahaan tidak mengalami kerugian yang lebih besar.

Tabel 6. Hasil Keseluruhan Pengujian Hipotesis

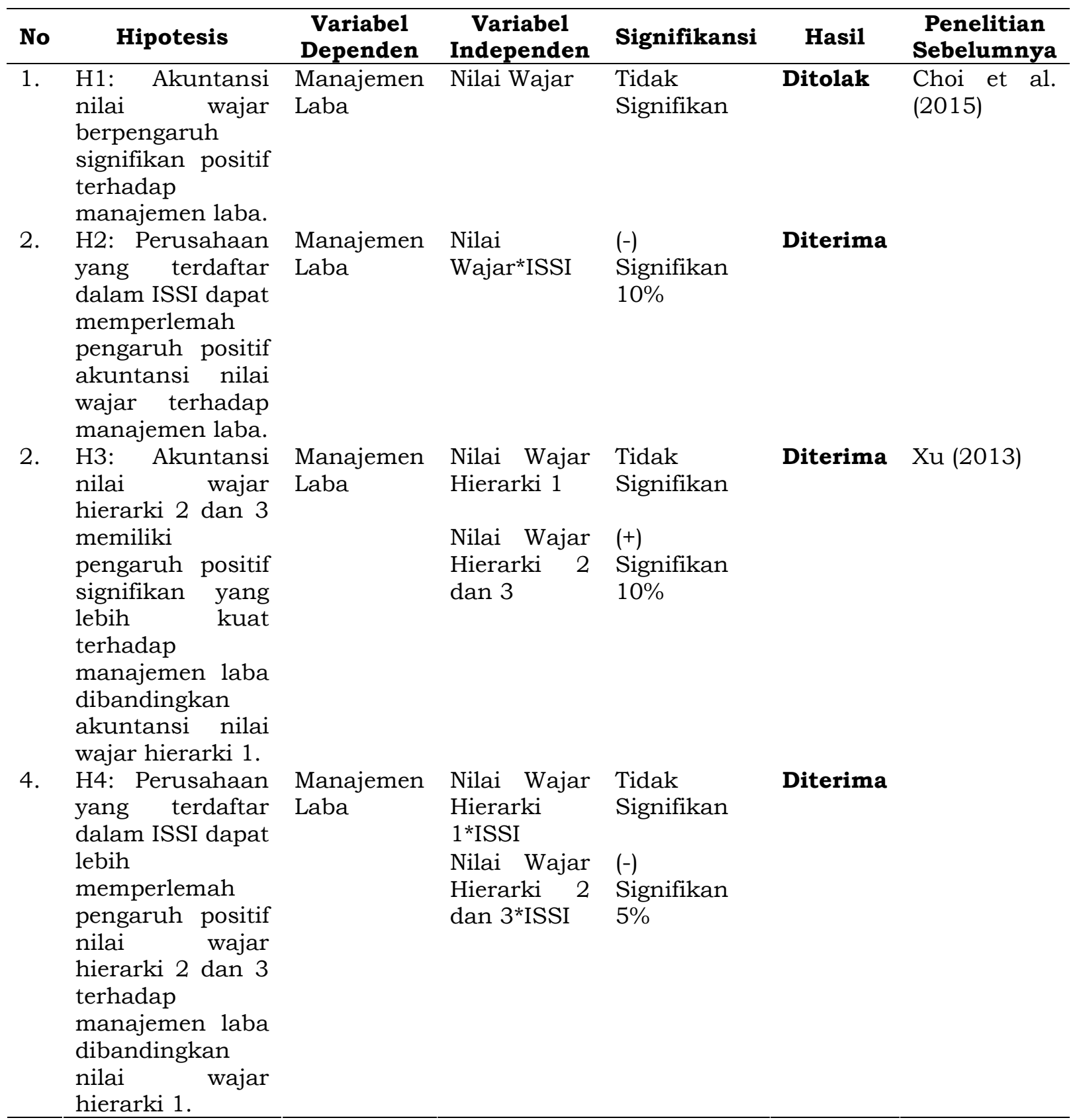

\section{KESIMPULAN, IMPLIKASI DAN KETERBATASAN PENELITIAN}

Tujuan dari penelitian ini adalah untuk menganalisis pengaruh nilai wajar (fair value) terhadap manajemen laba yang dimoderasi oleh perusahaan yang terdaftar dalam Indeks Saham Syariah Indonesia 
(ISSI). Pengujian dilakukan dalam rentang waktu 2012 sampai dengan 2016. Pengujian ini melibatkan 192 perusahaan yang listing di Bursa Efek Indonesia (BEI) sebagai sampel penelitian dengan total observasi sebesar 960 firm years.

Berdasarkan hasil pengujian hipotesis dan analisis data yang telah dilakukan, dapat disimpulkan bahwa hasil penelitian ini memberikan bukti empiris bahwa akuntansi nilai wajar tidak berpengaruh signifikan positif terhadap manajemen laba. Hal tersebut mengindikasikan bahwa nilai wajar bukanlah alternatif utama bagi manajer untuk melakukan manajemen laba.Ketika nilai wajar tersebut dibagi berdasarkan hierarkinya didapatkan hasil penelitian bahwa akuntansi nilai wajar hierarki 2 dan 3 memiliki pengaruh positif signifikan yang lebih kuat terhadap manajemen laba dibandingkan akuntansi nilai wajar hierarki 1.

Selain itu, hasil penelitian ini memberikan bukti empiris bahwa perusahaan yang terdaftar dalam ISSI memperlemah pengaruh positif akuntansi nilai wajar terhadap manajemen laba. Yang artinya, perusahaan yang terdaftar dalam ISSI terbukti mampu menekankan untuk menggunakan pengukuran nilai wajar dengan basis penilaian yang kuat, sehingga mampu mengurangi manajemen laba. Ketika nilai wajar dibagi berdasarkan hierarkinya didapatkan bahwa perusahaan yang terdaftar dalam ISSI dapat lebih memperlemah pengaruh positif nilai wajar hierarki 2 dan 3 terhadap manajemen laba dibandingkan hierarki 1 nilai wajar.

Beberapa keterbatasan di dalam penelitian ini adalah manajemen laba yang digunakan dalam penelitian yaitu manajemen laba akrual. Dengan demikian, penelitian selanjutnya dapat menelusuri manajemen laba riil sebagai variabel independennya. Selain itu, sampel penelitian tidak memasukkan perusahaan yang tergolong industri jasa keuangan. Penelitian selanjutnya dapat memperluas sampel penelitian ke perusahaan keuangan, lalu diperbandingkan apakah mendapatkan hasil yang berbeda atau tidak. Penelitian menggabungkan seluruh perusahaan dalam pengujian yang dilakukan sehingga tidak menjawab perbedaan pengukuran nilai wajar tiap industri. Penelitian selanjutnya diharapkan dapat memisahkan dan melakukan pengujian tersebut.

Penelitian memiliki beberapa implikasi. Pertama, penelitian ini dapat menyempurnakan penelitian sebelumnya terkait pengaruh 
akuntansi nilai wajar terhadap manajemen laba.Selain itu, penelitian ini secara empiris membuktikan bahwa terdapat perusahaan yang terdaftar dalam ISSI dapat memoderasi pengaruh akuntansi nilai wajar terhadap manajemen laba. Kedua, bagi regulator diharapkan melakukan pengawasan berbeda atas perusahaan yang tidak terdaftar dalam ISSI dengan perusahaan yang terdaftar dalam ISSI dikarenakan kualitas laba yang berbeda. Ketiga,hasil penelitian ini bergunabagi investor dapat dijadikan sebagai salah satu pertimbangan analisis investasi bahwa perusahaan yang terdaftar dalam ISSI dengan adanya pengukuran nilai wajar menghasilkan kualitas laba yang berbeda dibandingkan dengan perusahaan yang tidak terdaftar dalam ISSI.

\section{REFERENSI}

Badia, Marc. Duro, Miguel. Penalva, Fernando. and Ryan, Stephen. (2017). Conditionally Conservative Fair Value Measurement. Journal of Accounting and Economics, 63(1): 75-98.

Choi, Jongmoo Jay. Mao, Connie X.and Upadhyay, Arun D. (2015). Earnings Management and Derivative Hedging with Fair Valuation: Evidence from the Effects of FAS 133. Accounting Review, 90(4): 1437-1467.
Dechow, Patricia M. Myers, Linda A.and Shakespeare, Catherine. (2010). Fair Value Accounting and Gains from Asset Securitizations: A Convenient Earnings Management Tool with Compensation SideBenefits.Journal of Accounting and Economics, 49(1-2): 2-25.

Ehalaiye, Dimu. Tippett, Mark.and Zijl, Tony Van. (2017). The Predictive Value of Bank Fair Value. Pasific-Basin Finance Journal, 41: 111-127.

Farooq, Omar.and AbdelBari, Allaa. (2015). Earnings Management Behaviour of ShariahCompliant Firms and NonShariah-Compliant Firms Evidence from the MENA Region.Journal of Islamic Accounting and Business Research, 6(2): 173 - 188.

Farger, Neil.and Zhang, John Ziyang. (2014). Changes in The Measurement of Fair Value: Implications for Accounting Earning. Accounting Forum.

Francis, Jere R.and Wang, Dechun. (2008). The Joint Effect of Investor Protection and Big 4 Audits on Earnings Quality around the World. Contemporary Accounting Research, 25(1): 1-39.

Gaio, Cristina. (2010). The Relative Importance of Firm and Country Characteristics for Earnings Quality around the World. European Accounting Review, 19(4): 693-738.

Greiner, Adam J. (2015). The Effect of the Fair Value Option on Bank Earnings and Regulatory Capital Management: Evidence from Realized Securities Gains and Losses. Advances in Accounting, incorporating Advances in 
International Accounting, 31(1): 33-41.

Hameed, Shahul. Pramano, Sigit. Alrazi, Bakhtiar.and Bahrom, Nazli. (2004). Alternative Disclosure\& Performance Measure for Islamic Banks. Paper presented at International Conference on Administrative Sciences: Meeting the Challenges of the Globalization Age, King Fahd University of Petroleum \& Minerals, Dhahran, Saudi Arabia, 19-21.

$\mathrm{Hu}$, Fang. Percy, Majella.and Yao, Daifei. (2015). Asset Revaluations and Earnings Management: Evidence from Australian Companies. Corporate Ownership and Control, 13(1): 1287-1296.

Iatridis, George Emmanuel.\& Kilirgiotis, George. (2012). Incentives for Fixed Asset Revaluations: the UK Evidence. Journal of Applied Accounting Research, 13(1): 5 - 20 .

Ismail, Wan Adibah Wan. Kamarudin, Khairul Anuar.and Sarman, Siti Rahayu. (2015). The Quality of Earnings in ShariahCompliant Companies: Evidence from Malaysia. Journal of Islamic Accounting and Business Research, 6(1): $19-41$.

Kim, Yongtae. Park, Myung Seok.and Wier, Benson. (2012). Is Earnings Quality Associated with Corporate Social Responsibility?.The Accounting Review, 87(3): 761-796.

Kothari, S.P. Leone, Andrew J.and Wasley, Charles E. (2005). Performance Matched Discretionary Accrual Measures. Journal of
Accounting and Economics, 39(1): 163-197.

Lang, M.and Lundholm, R. (1993). Cross-sectional Determinants of Analysts Ratings of Corporate Disclosure. Journal of Accounting Research, 31(2): 246- 271.

Majid, Jamaluddin.and Haliding, Safri. (2014). The Critical Aspect on Fair Value Accounting and Its Implication to Islamic Financial Institutions. Al-Iqtishad. VI (2): 283-304.

Obid, Siti Normala., \& Demikha, Lotfi. (2011). Earning Management: Islamic Perspective. Asia Pacific Journal of Accounting and Finance, 2(1), 77-89.

Siekkinen, Jimi. (2016). Board Characteristics and the Value Relevance of Fair Values.Journal of Management and Governance, 21(2): 435471.

Sodan, Slavko. (2015). The Impact of Fair Value Accounting on Earning Quality in Eastern European Countries. Procedia Economics and Finance, 32: 1769-1786.

Wahyuni, Ika Sari. (2017). Assessment of Fair Value Accounting from the Islamic Perspective. Journal of Accounting, Auditing, and Performance Evaluation,13 (14), 325-338.

$\mathrm{Xu}$, Xiaolu. (2013). Fair Value Measurements And Earnings Management: Evidence From The Banking Industry.Ph.D Dissertation, Syracuse University, New York, United State. 
Jurnal Imiah Akuntansi • Vol. 2, No. 2, hal: 191-213 • Desember 2017 